\title{
Treatment of landfill leachate by electrocoagulation using aluminum electrodes
}

\author{
Rusdianasari $^{1, *}$, Ahmad Taqwa $^{2}$, Jaksen $^{1}$, and Adi Syakdani ${ }^{1}$ \\ ${ }^{1}$ Chemical Engineering Department State Polytechnic of Sriwijaya, 30139 Palembang, Indonesia \\ ${ }^{2}$ Electrical Engineering Department State Polytechnic of Sriwijaya, 30139 Palembang, Indonesia
}

\begin{abstract}
Leachate is wastewater decomposition of organic waste that can contaminate soil and groundwater if it is not handle properly. Contamination by leachate can be be prevented by reducing leachate level before the wastewater reaches the ground. One of the methods used is electrocoagulation. Electrocoagulation is an electrochemical water treatment method where in anoda occured the release of active coagulant as metalic ion, while in cathode occured the electrolysis reaction in a form of the release of hydrogen gas. This study is objected to investigate the effectiveness of electrocoagulation in removing Biochemical Oxygen Demand $\left(\mathrm{BOD}_{5}\right)$, Chemical Oxygen Demand (COD), $\mathrm{NH}_{3}-\mathrm{N}$ and lead $(\mathrm{Pb})$ of leachate. In this research, the processing of leachate with electrocoagulation method using aluminum electrode has been proceed with the dimension of electrode $16.5 \mathrm{~cm} \mathrm{x} 7 \mathrm{~cm}$ x $0.2 \mathrm{~cm}$. Optimum conditions and the effectiveness of electrocoagulation for each parameter are in the current density $30 \mathrm{~A} / \mathrm{m}^{2}$ with 60 minutes of time process. The electrocoagulation method is effectively reduced the value of TSS $46.80 \%$; $\mathrm{BOD}_{5} 71.33 \%$; $\mathrm{COD} 73.77 \%$; $\mathrm{Pb} 62.5 \%$; $\mathrm{NH}_{3}-\mathrm{N} 57.92 \%$; and for the increased of $\mathrm{pH}$ from 8.03 to 8.95 , respectively. Electrocoagulation method are successfully reduced the levels of pollutants in accordance with environmental standard.
\end{abstract}

\section{Introduction}

Landfilling is the most common and easy way to dispose the solid waste. Landfill is commonly received the wastes from municipal near to a landfill. If the location of waste generated is far, the transfer station is the solution to reduce cost of waste transportation. The waste usually mixed of waste products from residential area, commercial, institutional and others.

There are three kinds of output for landfills, examples gas, liquid (leachate) and inert solids [1]. Leachate has a complex structure and high pollutant load, and its treatment is quite hard to meet the discharge standards. Leachate becomes the main pollutant wastewater since it is the most difficult to treat as it is a wastewater with complex and widely variable content generated within a landfill [2]. Leachates may contain organic contaminants in large amounts and can be measured as Biochemical Oxygen Demand $\left(\mathrm{BOD}_{5}\right)$, Chemical Oxygen Demand (COD), ammonia, and high concentration of heavy metals. It contains high concentration of pollutants which can have adverse effects on the environment [3]. Therefore, many pretreatment and combined treatment methods have been proven to treat leachate. Until today, many methods for its treatment have been proven. Some well known treatment methods such as biological treatment methods, membrane processes, advanced oxidation techniques [4], coagulation-flocculation methods, lagoon and wetland applications [5], have been examined in the literature.

Simple, affordable, and efficient leachate treatment systems are urgently needed in developing countries because most of the conventional technologies currently in use in industrialized nations are too expensive and complex. Electrocoagulation is one of a simple method to treat wastewater efficiently [4]. This electrochemical treatment seems to be a promising treatment method due its high effectiveness, its lower maintenance cost, less need for labor and rapid achievement of results. From some research, in the past few decades, it shows that the electrocoagulation is a promising treatment method and effectively potential to treat verity type of wastewater including dyes wastewater, palm oil mill effluent, food wastewater, urban wastewater, and removing heavy metals [5].

Electrocoagulation has been used in treating wastewater containing oil and grease, suspended solids and even inorganic and organic pollutants that can be flocculated. This method has been effectively applied for the treatment of the textile dye wastewater, purification of wastewater, tannery wastewater and domestic wastewater. This method is categorized by simple equipment and easy operation. The electrocoagulation processes have lesser amount of sludge [6] and having

Corresponding author: rusdianasari19@gmail.com 
features like relatively more economic and higher treatment efficiency has been a promising method [7].

Electrocoagulation treatment methods offer an alternative to the use of chemical coagulant such as metal salts or polymers for breaking the pollutants because during the electrocoagulation process, the electrode can generate coagulated species and metal hydroxides that destabilize and aggregate the suspended particles and precipitate. The hydrogen gas released from cathode would also help to float the flocculated particles out of the water [8]. Electrocoagulation process is a consistent and coast effective method with low amount of sludge and without any sensitivity to toxic materials. In the electrocoagulation process coagulant is produced by electrolytic oxidation of an appropriate sacrificial anode by suing a direct current. The electrocoagulation mechanism for aluminum electrode could be represented as follow [9]:

$$
\begin{aligned}
& A l_{(s)} \rightarrow A l_{(a q)}^{3+}+3 e^{-} \\
& 3 \mathrm{H}_{2} \mathrm{O}+3 \mathrm{e}^{-} \rightarrow 3 / 2 \mathrm{H}_{2(\mathrm{~g})}+3 \mathrm{OH}_{(\mathrm{aq})}^{-} \\
& \mathrm{Al}_{3}^{+}{ }_{(a q)}+3 \mathrm{OH}_{(a q)} \rightarrow A l(\mathrm{OH})_{3(s)}
\end{aligned}
$$

The experiments were carried out in a batch mode to evaluate effect of different operational variables like $\mathrm{pH}$, current density, $\mathrm{BOD}_{5}, \mathrm{COD}, \mathrm{TSS}, \mathrm{NH}_{3}-\mathrm{N}$, and heavy metal removal of leachate wastewater.

\section{Materials and methods}

\subsection{Leachate sample}

In the experimental study, leachate samples were collected from Sukawinatan Landfill, which is located in Palembang city, Indonesia. The samples were collected in glass bottles transported in ice cool container to the laboratory and stored at $4^{\circ} \mathrm{C}$ in order to keep the leachate characteristics unchanged.

\subsection{Experimental device}

The batch experimental setup is schematically shown in Fig.1.

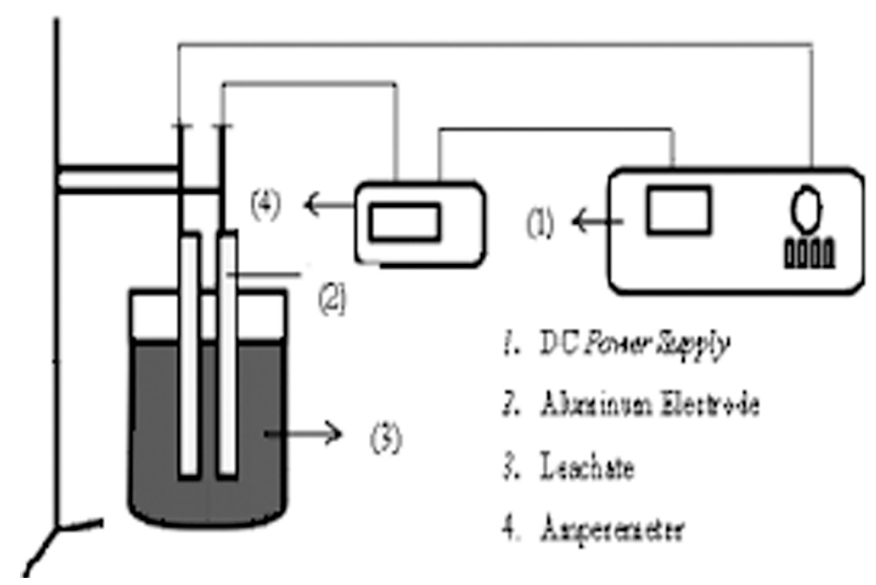

Fig. 1. Schematic diagram of experimental setup
The electrochemical unit consists of an electrocoagulation cell, a DC power supply and the aluminum electrodes. There are two monopolar electrodes that have same dimension $(16.5 \mathrm{~cm} \mathrm{x} 7 \mathrm{~cm} \mathrm{x}$ $0.2 \mathrm{~cm}$ ) as an anode and a cathode which spacing of 1 $\mathrm{cm}$ which were placed vertically in the floor of the cell.. In order to maintain an unchanged composition and avoid the association of the flocs in the solution, the stirrer was turned on and set at $100 \mathrm{rpm}$. All electrodes were washed with dilute $\mathrm{HCl}$ before every experiment conducted. Every experiment was performed at the room temperature.

\subsection{Experiment procedure}

The procedure started with electrocoagulation cell cleaned with distilled water and dried using dryer. The experiments were carried out in a batch mode. For each experiment, a leachate sample of $1 \mathrm{~L}$ was collected in the electrochemical cell with aluminum electrodes dipped into the sample. Four different of high current densities; $30 \mathrm{~A} / \mathrm{m}^{2}, 50 \mathrm{~A} / \mathrm{m}^{2}, 70 \mathrm{~A} / \mathrm{m}^{2}$ and $90 \mathrm{~A} / \mathrm{m}^{2}$ were applied. In each current density applied, contact times of 15,30 , 45 , and 60 were used. Therefore, total experiments were carried out to determine the effect of current densities, electrocoagulation time and effectiveness of electrocoagulation. The $\mathrm{pH}$ of the solution was taken using $\mathrm{pH}$ meter. The electrodes (anode and cathode) were clamped at electrode stand. All connections in the circuit were completed by wire connection to terminal positive and negative to DC power supply, electrodes (anode and cathode), voltmeter and ampere meter.

The colour of the solution of electrolyte solution was observed before and after the process occurred. After the experiment, the treated sample was then kept undisturbed for $20 \mathrm{~min}$ in order to allow the flocs to settle. Subsequently, after settling the sample of supernatant was collected to perform the analysis of $\mathrm{pH}$, TSS, BOD5, COD, lead metal and content of $\mathrm{NH}_{3}-\mathrm{N}$. All the experiments were repeated with same operational conditions using aluminium electrodes (both anode and cathode). For the treated effluent $\mathrm{BOD}_{5}, \mathrm{COD}$, TSS and $\mathrm{NH}_{3}-\mathrm{N}$ were measured according to Standard Methods after each batch run.

\section{Results and discussion}

The electrocoagulation process was influenced by operating parameters such as current density, and reaction time on removal of $\mathrm{BOD}_{5}, \mathrm{COD}, \mathrm{TSS}, \mathrm{NH}_{3}-\mathrm{N}$, and $\mathrm{Pb}$ concentration. $\mathrm{Pb}$ concentration was measured by atomic absorption spectrophotometer.

\subsection{Characteristic of the landfill leachate}

Several parameters such as the people living standards of the study area, landfill age, and climatic condition affected to the composition and characteristic of the landfill leachate. To this aim at different time the sampling was performed and various water treatment 
criteria such as $\mathrm{pH}, \mathrm{BOD}_{5}, \mathrm{COD}, \mathrm{TSS}, \mathrm{NH}_{3}-\mathrm{N}$ and $\mathrm{Pb}$ concentration were used to assess characteristics of landfill leachate which are presented in the Table I. The conventional biological methods are ineffective to treatment of the leachate because it has high ammonia nitrogen. According to literatures to treat a wastewater with mentioned characteristic, electrocoagulation method is an effective method [10].

Table 1. Characteristics of the landfill leachate before treatment

\begin{tabular}{|c|l|c|c|}
\hline No & Characteristics & Value & $\begin{array}{c}\text { Treshold } \\
\text { Standard }^{*}\end{array}$ \\
\hline 1 & $\mathrm{pH}$ & 8.03 & $6-9$ \\
\hline 2 & $\mathrm{BOD}_{5}(\mathrm{mg} / \mathrm{L})$ & 112.6 & 200 \\
\hline 3 & $\mathrm{COD}(\mathrm{mg} / \mathrm{L})$ & 415 & 50 \\
\hline 4 & $\mathrm{TSS}(\mathrm{mg} / \mathrm{L})$ & 1304 & 100 \\
\hline 5 & $\mathrm{NH}_{3}-\mathrm{N}(\mathrm{mg} / \mathrm{L})$ & 2.4 & 1 \\
\hline 6 & $\mathrm{~Pb}$ content $(\mathrm{mg} / \mathrm{L})$ & 0.08 & 0.1 \\
\hline
\end{tabular}

*South Sumatra Governor Regulation No. 6 of 2012

It can be seen from the analysis that the parameters that need to improve in order to meet the disposal standards of leachate include COD, TSS, and $\mathrm{NH}_{3}-\mathrm{N}$.

\subsection{Effect of current density to processing time for $\mathrm{pH}$}

This experimental work used ranges current density of $30 \mathrm{~A} / \mathrm{m}^{2}, 50 \mathrm{~A} / \mathrm{m}^{2}, 70 \mathrm{~A} / \mathrm{m}^{2}$ and $90 \mathrm{~A} / \mathrm{m}^{2}$. These ranges will give the data about how current density will affect the electrocoagulation efficiency in the removal of pollutants that contain in the leachate samples.

As shown in Fig. 2, we can see the increase of leachate $\mathrm{pH}$. The initial $\mathrm{pH}$ was 8.03 categorized in base category. After treatment there was significantly increase of $\mathrm{pH}$. The $\mathrm{pH}$ reached 8.95. The increase of $\mathrm{pH}$ in the electrocoagulation process was due to the process of alkalization $\mathrm{Al}^{3+}$ ions that were added to the water and reacted with hydroxyl ions from water hydrolysis that produced $\mathrm{Al}(\mathrm{OH})_{3}$ and hydrogen ions.

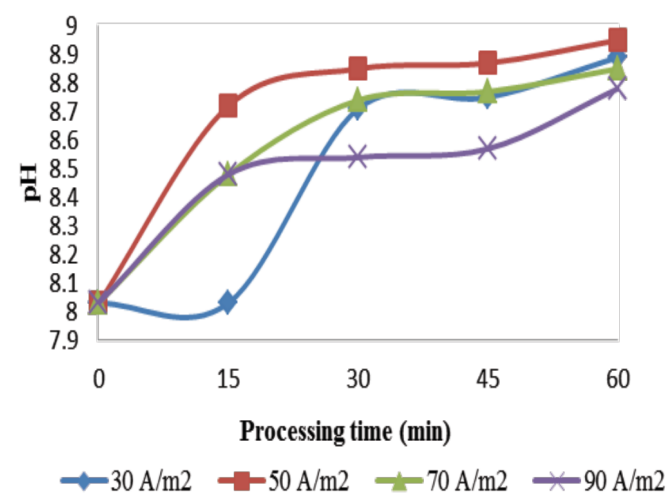

Fig. 2. The effect of current density to processing time for $\mathrm{pH}$

In addition to hydrogen gas, it also generated hydroxide ions $(\mathrm{OH})^{-}$, the smaller the current density used the faster the reaction might occurred and $\mathrm{OH}^{-}$ generated also more in consequence the $\mathrm{pH}$ in the water would also increase. The occurrence of such reactions during the electrocoagulation process would raise the $\mathrm{pH}$ [11].

In Fig. 2, it can be seen that the $\mathrm{pH}$ tended to increase with the length of 7-8. The best results in the increase in $\mathrm{pH}$ of 8.95 occured in the current density of $50 \mathrm{~A} / \mathrm{m}^{2}$ in $60 \mathrm{~min}$.

\subsection{Effect of Current Density to Processing Time for TSS}

TSS reduction in the electrocoagulation process occurred when the solid material of the suspended solids in the coagulant absorbed onto $\mathrm{Al}(\mathrm{OH}) 3$ or absorbed into the air bubble. The results of this adsorption were floated that decrease the concentration of TSS in wastewater.

TSS sources of pollutants were chemicals both organic and inorganic that formed suspension in the waste water. Besides that the sources of TSS also came from metals that formed complex compounds either with hydroxide anions or other compound suspended in the waste solution either because of the nature of the molecular size of the compounds and polarity properties [12].

As shown in Fig. 3, we can see the results of electrocoagulation of leachate. The best result in impairment of TSS was at $60 \mathrm{~min}$ with current density of $30 \mathrm{~A} / \mathrm{m}^{2}$ in which the initial TSS value of $112.6 \mathrm{mg} / \mathrm{L}$ impaired to $59.9 \mathrm{mg} / \mathrm{L}$. TSS reduction process were highly influential that TSS were pollutants in the form of suspension. If waste water contained high TSS, it could be concluded that the waste water was in poor quality and had the potential to damage the aquatic ecosystem in particular.

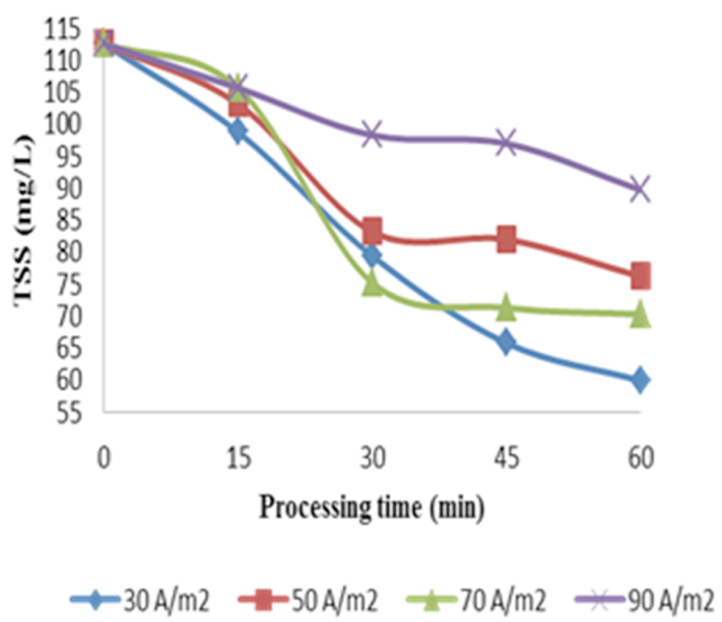

Fig. 3. The effect of current density to processing time for TSS

According to Islam et al. [13], the two main objectives of the coagulation are to settle the suspended colloidal particles in wastewater quickly, which settle very slowly, or maybe do not settle at all under normal conditions, later leading to residuals TSS, and to remove TSS from the leachate/wastewater and consequently to obtain clearer leachate/wastewater, which is a natural result of the earlier. 


\subsection{Effect of current density to processing time for $\mathrm{BOD}_{5}$}

Result of $\mathrm{BOD}_{5}$ analysis determined the quality of water bodies, amount of oxygen needed by microorganisms to decompose organic matter contained in water in the aerobic state. $\mathrm{BOD}_{5}$ high value played an important role in determining the ability of the water bodies in supporting the better growth of algae and aquatic organisms. The higher the number of the bacterial population, the higher the level of the water pollution would be.

In Fig. 4, the results of electrocoagulation of leachate to the value of $\mathrm{BOD}_{5}$ decreased. The best result of $\mathrm{BOD}_{5}$ impairment was at $60 \mathrm{~min}$ and current density of 30 $\mathrm{A} / \mathrm{m}^{2}$ with a value of $\mathrm{BOD}_{5} 119 \mathrm{mg} / \mathrm{L}$. At this process time, there was significant change in the value of $\mathrm{BOD}_{5}$ from $415 \mathrm{mg} / \mathrm{L}$ to $119 \mathrm{mg} / \mathrm{L}$, yet the greater the current density, the greater the value of $\mathrm{BOD}_{5}$ would slightly rise. The greater the density current and the longer the time, the electrode process would be more saturated that caused the electrocoagulation process reached its lowest point and increased in the value of $\mathrm{BOD}_{5}$.

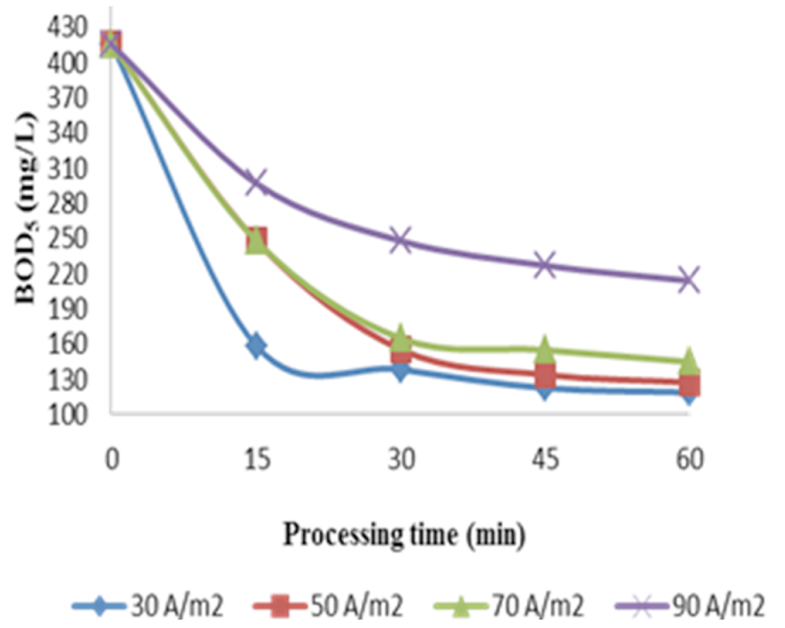

Fig. 4. The effect of current density to processing time for $\mathrm{BOD}_{5}$

\subsection{The effect of current density to processing time for COD}

COD was the quantity or amount of oxidant that reacted with the sample under certain conditions. The amount of oxidant was proportional to the oxygen. Organic and inorganic compounds in the sample were oxidized subject but organic compounds were more dominant. COD was often used for measuring the quantity of pollutants in the water.

In Fig. 5, the best result of leachate waste by method of electrocoagulation in decreasing the value of COD was at $60 \mathrm{~min}$ with a current density of $30 \mathrm{~A} / \mathrm{m}^{2}$. COD value decreased drastically from $1304 \mathrm{mg} / \mathrm{L}$ to 342 $\mathrm{mg} / \mathrm{L}$.

Basically, the decline in COD values in electrocoagulation occured by destabilization. Colloidal destabilization carried out by metal cation that formed polyvalen polyhydroxide. This complex compound had high adsorption for facilitating aggregation of wide range of pollutants that formed large material easily separated by flotation technique since the density of material became smaller [14].

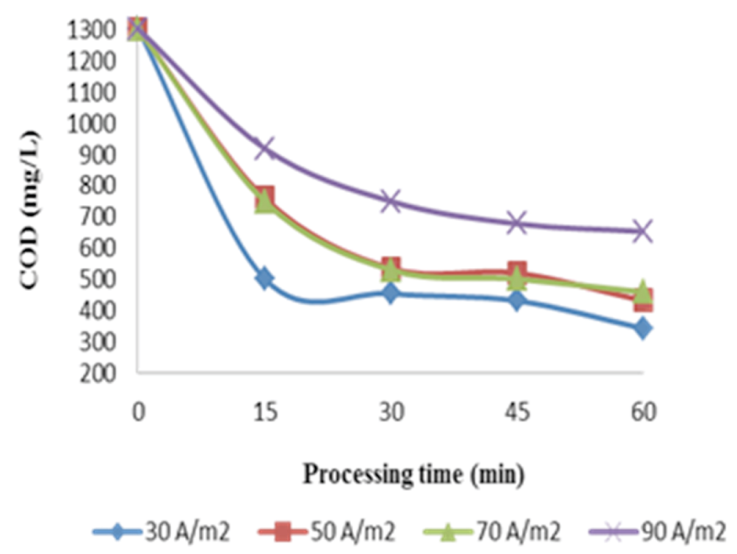

Fig. 5. The effect of current density to processing time for COD

\subsection{Effect of current density to processing time for $\mathrm{Pb}$ metal}

Based on the experiments, data showed that any change in current density and the length of time would generate different electrocoagulation efficiency. The longer the contact time, the lower the level of $\mathrm{Pb}$ metal in the filtrate would obtain for any variations in current density. In Fig. 6, it can be seen that $\mathrm{Pb}$ metal reduction of the biggest waste was achieved at runtime of $60 \mathrm{~min}$ and current density of $30 \mathrm{~A} / \mathrm{m}^{2}$. In this condition, the level of $\mathrm{Pb}$ metal in the filtrate was $342 \mathrm{mg} / \mathrm{L}$.

The decreased level of $\mathrm{Pb}$ metal in the process of electrolysis might occur due to changes in electrical currents causing magnetic field around the electrodes. The $\mathrm{Pb}$ ions moved with trajectories helix shape around the electrode plate so that at that time there was tendency of $\mathrm{Pb}^{2+}$ ions to attach to the entire surface of the electrode plate.

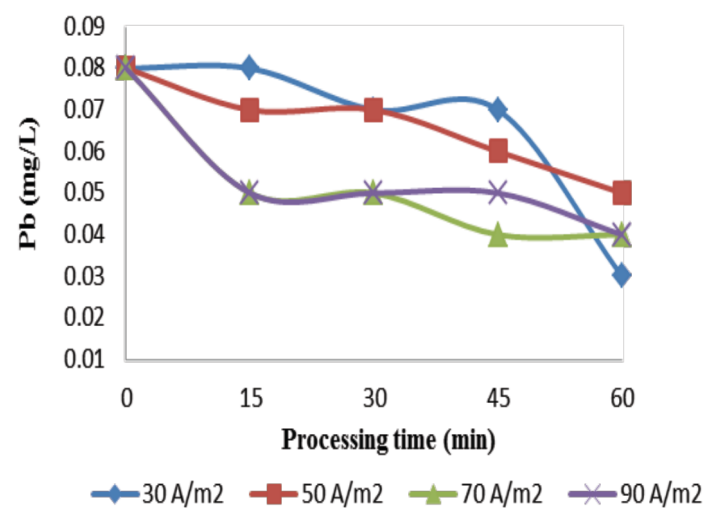

Fig. 6. The effect of current density to processing time for $\mathrm{Pb}$ metal

In an electrochemical process, at the same time the electric current in the anode reaction will occur in the 
oxidation of the anion (negative ion), an anode made of aluminum metal would undergo oxidation reactions to form $\mathrm{Al}^{3+}$ ion and would bind $\mathrm{OH}^{-}$ions forming flock $\mathrm{Al}(\mathrm{OH})_{3}$ which can bind $\mathrm{Pb}^{2+}$ ions and capture most of $\mathrm{Pb}$ that was not deposited on the cathode rod $[15,16]$.

\subsection{Effect of current density to processing time for the content of $\mathrm{NH}_{3}-\mathrm{N}$}

The decrease content of $\mathrm{NH}_{3}-\mathrm{N}$ in the electrocoagulation process for liquid waste from leachate was very important. This was because ammonia $\left(\mathrm{NH}_{3}\right)$ called ammonia nitrogen was produced from the decay of organic substances by bacteria. Each of ammonia released into the environment formed an equilibrium reaction with ammonium ion $\left(\mathrm{NH}_{4}{ }^{+}\right)$. Ammonium then underwent nitrification to form nitrite and nitrate. Ammonia that was dissociated was more dangerous to aquatic biota instead of in the ammonium form. The value of ammonia was related to the $\mathrm{pH}$ value of water. The higher the $\mathrm{pH}$ of the water, the greater the ammonia content in the form of dissociated. High ammonia level was indication of contamination of organic material originating from domestic waste, industrial, and agricultural fertilizer runoff $[17,18]$.

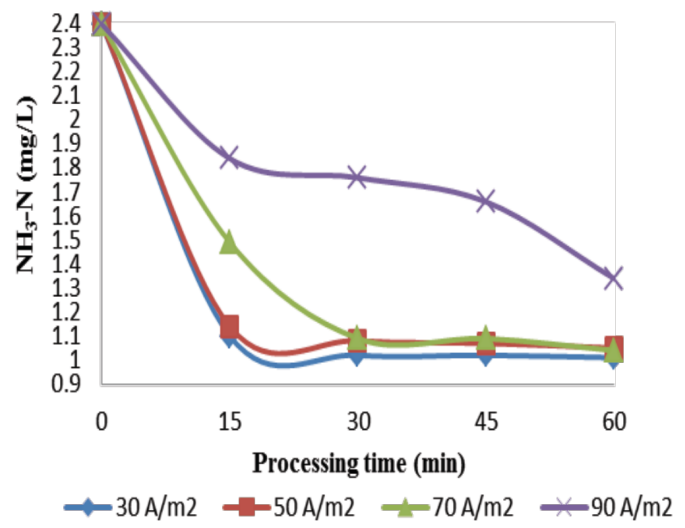

Fig. 7. The effect of current density to processing time for the content of $\mathrm{NH}_{3}-\mathrm{N}$

In Fig. 7, the largest content reduction of $\mathrm{NH}_{3}-\mathrm{N}$ in leachate was achieved in $60 \mathrm{~min}$ at $30 \mathrm{~A} / \mathrm{m}^{2}$. In this condition the levels of $\mathrm{NH}_{3}-\mathrm{N}$ in the filtrate was 1.01 $\mathrm{mg} / \mathrm{L}$ from preliminary analysis of $2.4 \mathrm{mg} / \mathrm{L}$.

\subsection{The Effectiveness of electrocoagulation to the treatment leachate}

The decrease of pollutants contained in the leachate might be done by electrocoagulation. After the processing pollutants contained in the effluent decreased. The effectiveness of electrocoagulation in treating leachate with the parameters of TSS, $\mathrm{BOD}_{5}, \mathrm{COD}, \mathrm{NH}_{3}-$ $\mathrm{N}, \mathrm{Pb}$ levels and $\mathrm{pH}$ values were different.

TSS great decrease in the current density of $30 \mathrm{~A} / \mathrm{m}^{2}$ with a processing time of $60 \mathrm{~min}$ is $59.9 \mathrm{mg} / \mathrm{L}$. Decrease in $\mathrm{BOD}_{5}$ and COD are good at current density of 30 $\mathrm{A} / \mathrm{m}^{2}$ with a processing time of $60 \mathrm{~min}$ were $119 \mathrm{mg} / \mathrm{L}$ and $342 \mathrm{mg} / \mathrm{L}$. Decreased levels of $\mathrm{Pb}$ and $\mathrm{NH}_{3}-\mathrm{N}$ content of the nicest on a current density of $30 \mathrm{~A} / \mathrm{m}^{2}$ with a processing time of $60 \mathrm{~min}$ were $0.03 \mathrm{mg} / \mathrm{L}$ and $1.01 \mathrm{mg} / \mathrm{L}$. The increase in the $\mathrm{pH}$ value was good at current densities of $50 \mathrm{~A} / \mathrm{m}^{2}$ with a time of 60 min was 8.95 .

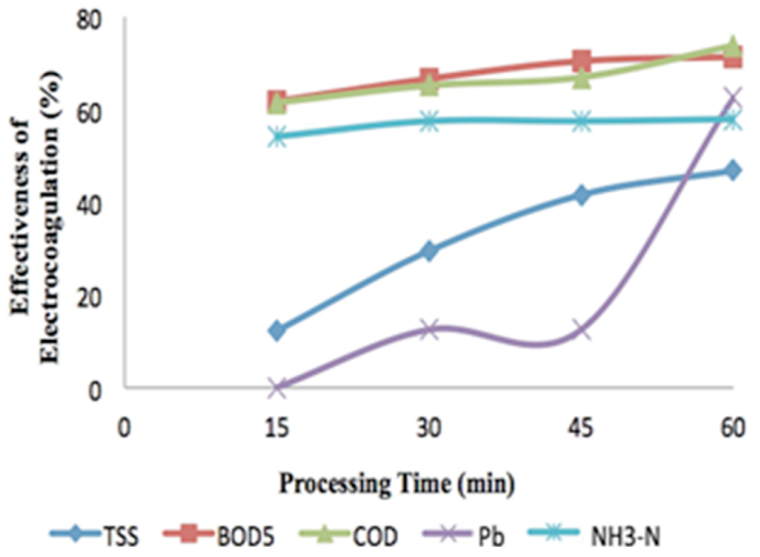

Fig. 8. Effectiveness of electrocoagulation to processing time on current density $30 \mathrm{~A} / \mathrm{m}^{2}$

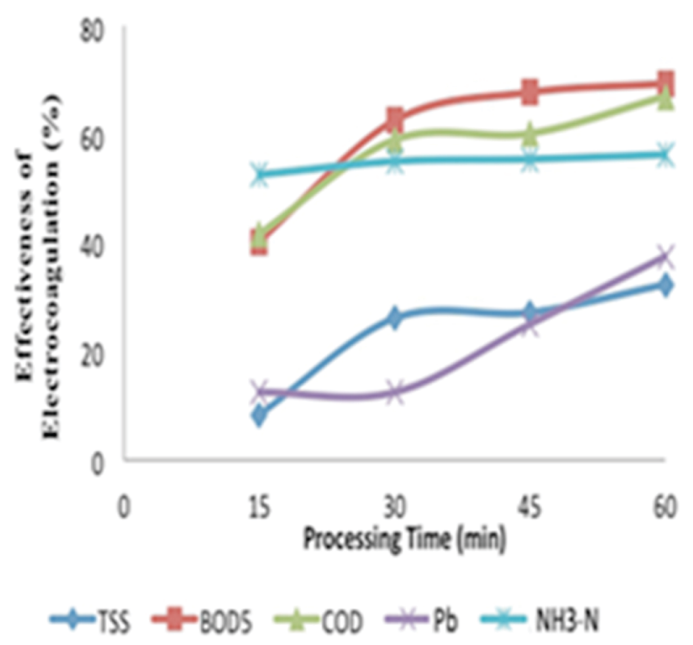

Fig. 9. Effectiveness of electrocoagulation to processing time on current density $50 \mathrm{~A} / \mathrm{m}^{2}$

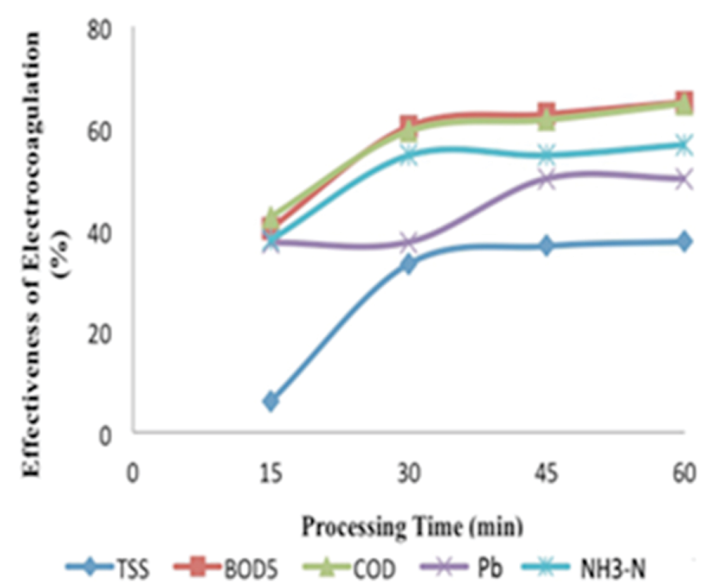

Fig. 10. Effectiveness of electrocoagulation to processing time on current density $70 \mathrm{~A} / \mathrm{m}^{2}$ 
Fig. 8-12 shown the effectiveness of the electrocoagulation versus processing time on the current density of $30 \mathrm{~A} / \mathrm{m}^{2}, 50 \mathrm{~A} / \mathrm{m}^{2}, 70 \mathrm{~A} / \mathrm{m}^{2}$, and $90 \mathrm{~A} / \mathrm{m}^{2}$ with a comparison between $\mathrm{TSS}, \mathrm{BOD}_{5}, \mathrm{COD}, \mathrm{NH}_{3}-\mathrm{N}$, and $\mathrm{Pb}$ concentration and shown the effectiveness of a decrease in $\mathrm{BOD}_{5}, \mathrm{COD}$ and $\mathrm{NH}_{3}-\mathrm{N}$ levels.

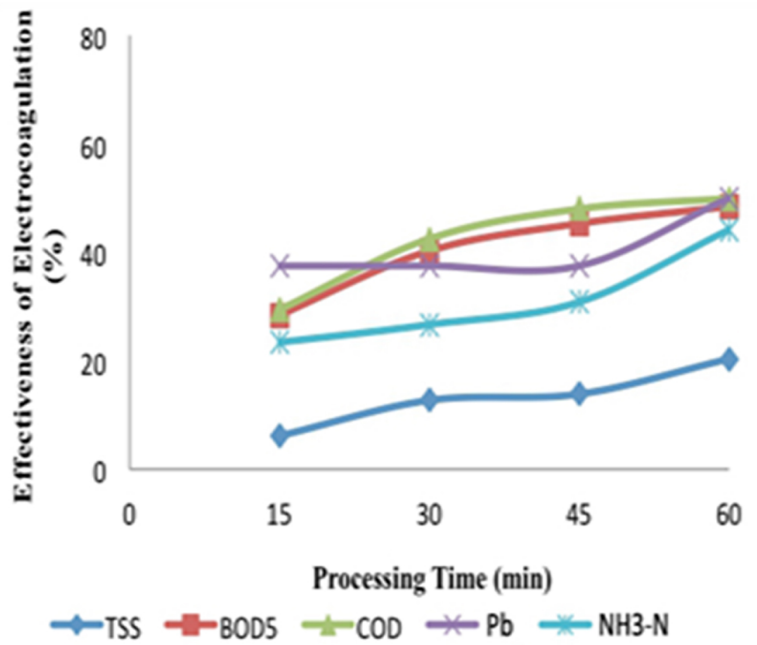

Fig. 11. Effectiveness of electrocoagulation to processing time on current density $90 \mathrm{~A} / \mathrm{m}^{2}$

The effectiveness for TSS was $46.80 \%$ from the initial sample of $112.6 \mathrm{mg} / \mathrm{L}$ to $59.9 \mathrm{mg} / \mathrm{L}$. The effectiveness for $\mathrm{BOD}_{5}$ was $71.33 \%$ from the initial sample of $415 \mathrm{mg} / \mathrm{L}$ to $119 \mathrm{mg} / \mathrm{L}$ and the effectiveness COD was $73.77 \%$ from the initial sample of $1304 \mathrm{mg} / \mathrm{L}$ to $342 \mathrm{mg} / \mathrm{L}$. The effectiveness for $\mathrm{Pb}$ metal was $62.5 \%$ from the initial sample of $0.08 \mathrm{mg} / \mathrm{L}$ to $0.03 \mathrm{mg} / \mathrm{L}$ and the effectiveness for $\mathrm{NH}_{3}-\mathrm{N}$ content was $57.92 \%$ from the initial sample of $2.4 \mathrm{mg} / \mathrm{L}$ to $1.01 \mathrm{mg} / \mathrm{L}$.

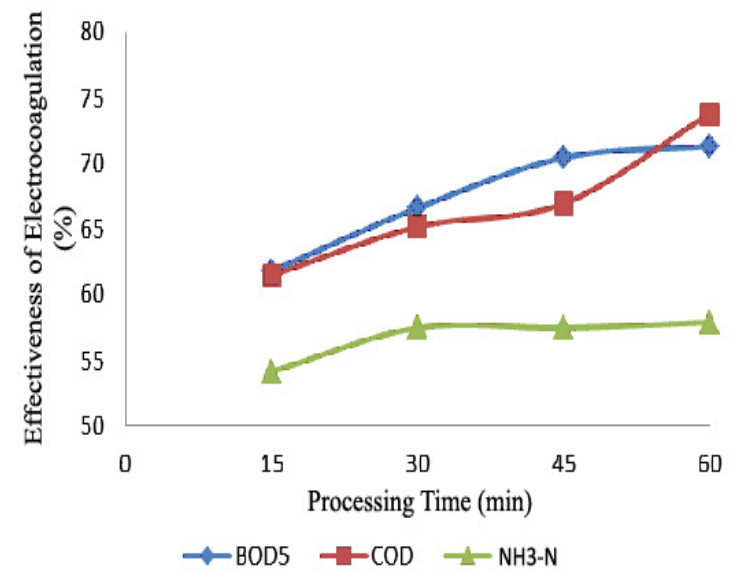

Fig. 12. The Effectiveness of Electrocoagulation to the values of BOD5, COD, and $\mathrm{NH}_{3}-\mathrm{N}$ Content

\section{Conclusions}

The effectiveness of electrocoagulation were investigated in this study. Optimum conditions and the effectiveness of electrocoagulation for each parameter are in the current density $30 \mathrm{~A} / \mathrm{m}^{2}$ with 60 minutes of time process. The electrocoagulation method is effectively reduced the value of TSS 46.80\%; BOD $_{5} 71.33 \%$; COD 73.77\%; $\mathrm{Pb} 62.5 \%$; $\mathrm{NH}_{3}-\mathrm{N}$ $57.92 \%$; and for the increased of $\mathrm{pH}$ from 8.03 to 8.95 , respectively. Electrocoagulation method are succesfully reduced levels of pollutants in accordance with environmental standard.

\section{References}

1. M. K. N. Mahmad, M. R. Rozainy, I. Abustan, N. Baharun. Procedia Chem. 19, 681-686 (2016)

2. E. S. Yusmartini, D. Setiabudidaya, Ridwan, Marsi, Faizal. J. of Phys: Conf. Series. 423 (2013)

3. B. MJK, I. MH, K. SRM. Waste Manag. 29, 9, 2534-2541 (2009)

4. Kamaruddin, M.A, M.S. Yusoff, AzizH.A. Appl. Water Sci. 5, 113-126 (2015)

5. M. Morozesk, M.M. Bonomo, L.D. Rocha, I.D. Duarte, E.R. Zenezi. Chemosphere 158, 66-71 (2016)

6. C. B. Shivayogimath, C. Watawati. Int. J. of Res. in Eng. and Tech. Nov, 266-269 (2013)

7. F. Ilhan, U. Kurt, O. Apaydin, M.T. Gonullu. J. Hazardous Materials 154, 381-389 (2008)

8. O. Dia, P. Drogui, G. Buelna, R. Dube, B. S. Ihsen. J. Chemosphere, 1-6 (2016

9. G. Hassani, A. Alinejad, A. Sadat, A. Esmaeili, M. Ziaei, A. A. Bazrafshan, T. Sadat. Int. J. Electrochem. Sci. 11, 6705-6718 (2016

10. Rusdianasari, Y. Bow, A. Taqwa. Adv. Materials Res. 896, 145-148 (2014)

11. Rusdianasari, A. Meidinariasty, I. Purnamasari. Int. J. on Adv. Sci. Eng. and Information Tech. 5, 6, 387-391 (2015)

12. M. A. Jumaah, M. R. Othman. Int. J. of Chem. Tech. Res. 8, 12, 604-609 (2015)

13. S.M.N. Islam, S.H. Rahman, M.M. Rahman. J. Sci. Res. 3, 3 (2011)

14. R. Bow, S. Arita, E. Ibrahim, N. Ngudiantoro. Appl. Mech. and Mat. 391, 29-33 (2013)

15. Y. Bow, Hairul, I. Hajar, Int. J. on Adv. Sci. Eng. and Inf. Tech. 5, 6, 422-425 (2015)

16. M. Poveda, Q. Yuan, J. Oleszkiewicz. Int. J. of Env. Csi. Dev. 7, 4 (2016)

17. C. Phalakornkule, J. Mangmeemak, K. Intrachod, Scienceasia 36, 1, 42-49 (2010)

18. C.B. Shivayogimath, C. Watawati. Int. J. of Ren. Energy and Env. Eng. 02, 03 (2014) 